\title{
REMARKS ABOUT THE TECTONICS OF THE GNEISSES OF CENTRAL BAFFIN ISLAND AND THE RISE OF THE INFRASTRUCTURE
}

\author{
E. H. KRANCK
}

\begin{abstract}
KRANCK, E. H. 1972: Remarks about the tectonics of the gneisses of central Baffin Island and the rise of the infrastructure. Bull. Geol. Soc. Finland 44, $111-$ 122.

In this paper some parallels are drawn between gneiss-tectonics of central Baffin Island and some similar localities elsewhere, and some general principles of migmatite tectonics are discussed.
\end{abstract}

E. H. Kranck, Hudson Heights, P. Box. 112, Quebec, Canada.

\section{Introduction}

Much new information has been gained about the bedrock of Baffin Island since my reconnaissance work in the Clyde region in 1950 (Kranck, 1953, 1955), at a time when we had no accurate maps and no air photographs. This work was continued in the McBeth river valley in the summers of 1966, 1967 and 1969 by Mr. N. Gray and Mr. R. Forester (1967). The now completed helicopter survey of Baffin Island by the Geological Survey of Canada, which is not yet fully in print, will give the first complete general picture of the geology of the island. Because of this additional knowledge, a re-examination of some earlier material was necessitated, and some earlier interpretations of the structures have had to be modified.

In this paper, the area mainly dealt with is the fiord region from Gibbs fiord southward to McBeth fiord, with the addition of some inland observations.
The bedrock belongs to an east-west trending Precambrian fold belt, probably extending to Fox basin and Melville peninsula (Gray, Forester, Jackson, 1969; Fahring, Irving, Jackson, 1969 and 1971). Two major structural elements can be distinguished in this belt: a supercrustal series consisting of metasediments and a minor amount of metavolcanics intersected by basic sills and dykes; and migmatites and granitoid plutonites. Normally the migmatites form the substratum below the supercrustal rocks, forming the infrastructure according to the terminology of Wegmann (Wegmann, 1935). The metasediments form the superstructure and transitional zone.

The only rocks younger than the migmatite assemblage are the numerous northwest-southeast trending gabbro-diabase dikes discussed in the papers by Gray (1970) and by Fahring, Irving and Jackson (1971). Late porphyritic granite of unknown age was found by the geologists of the Geological Survey of Canada in the Home bay region (Jackson 1971). 


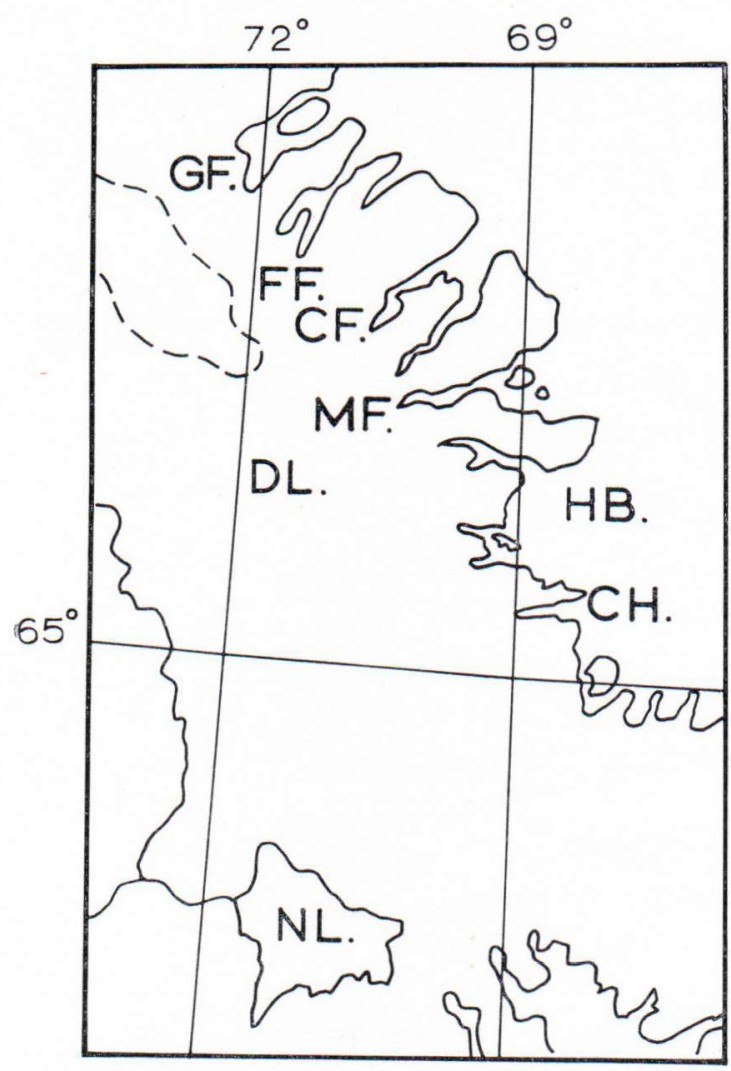

FIg. 1. Map showing the location of the area. GFGibbs Fiord, FF-Sam Ford Fiord, CF-Clyde Fiord, IF-Inugsuin Fiord, HB-Home Bay, CH-Cape Hooper, DL-Dewar Lake, NL-Nettiling Lake.

\section{The Metasediments}

The predominant metasediments *) form a thick series of biotite gneisses, rusty biotite schists and black phyllites, with oligoclase, quartz and varying amounts of potassium feldspar as main felsic components, and mostly containing some bornblende. Garnet, sillimanite and cordierite are common, particularly in the schists. Cyanite has also been found, but its position has not yet been established.

The original character of these rocks was greywacke and impure sandstone, siltstone and mudstone. The last-named gives rise to graphite and sulphide-rich black schist. Wellpreserved

\footnotetext{
*) They have been named the Piling Group by Jackson, 1971.
}

primary layering, crossbedding and ripple marks have been reported from the McBeth river valley by Grey and Forester (1967).

The best marker horizon in the region is a widespread horizon of dolomitic marble and skarn. The pure marble is partly very coarse grained, with grains up to 2 inches in diameter, partly fine-grained and highly tectonized. The colour is partly pure white, partly light lilac. The presence of a finegrained marble with strong bituminous odour at the head of Sam Ford Fiord is interesting, and may have some connection with the presence of carbonaceous mudstone in the vicinity. The skarn layers, interbedded with the marble, contain diopside, tremolite, chondrodite, phlogopite and epidote. Particularly in the Clyde river valley, very micaceous layess are common, probably formed by potassium metasomatism at the time of the granitization of the surrounding rock. In the McBeth Fiord area scapolite is a normal constituent of the skarn. A conspicuous contact rock is a siliceous layer containing round nodules of sillimanite and quartz, which seen from a distance resemble conglomerates.

The thickness of the marble horizon decreases from north to south and in McBeth valley is only from 30 to 50 feet.

Another characteristic marker horizon is a white, glassy quartzite, usually containing sillimanite. It is about 1000 feet thick on the south side of the head of McBeth Fiord, while in the Clyde river valley its thickness is only a few feet.

Iron formations have been found in the area only south of Barnes icecap. It is a rather typical, lowgrade, quartz-banded iron ore, with aluminum - rich layers containing garnet, andalusite and anthophyllite. The country rock is an impure quartzite.

The stratigraphic sequence of the metasediments is mostly disturbed by recumbent folding and by thrust faulting, but the original position seems to be preserved at the head of McBeth Fiord where the folıowing column is found: 
Uppermost 1. White glassy quartzite

2. Pelitic gneisses and mica schist

3. Black, sulphide-rich phyllitic schist

4. Marble and skarn

5. Migmatite gneisses and granites

This sequence may be local. According to Jackson (1971) quartzite is normally underlaying the marble horizon. This is also the case in the Clyde river valley.

\section{The Migmatites}

The fiord country of north western Baffin Island offers ideal conditions for the study of migmatites. The cliff walls along the fiords display all the types of migmatite structures listed in current classifications (Mehnert, 1968), and make it possible to carry out observations in all scales of the relationship between the different types in space, and also their relationship to the overlying metasediments.

The palaeosome consists predominantly of granitized pelitic material altered into a gray plagioclase gneiss, often quite homogeneous, but in other places veined and spotted with pegmatitic granite. Numerous mafic fragments are formed from basic dikes and sills, but also from $\mathrm{Ca}-\mathrm{Mg}-\mathrm{Fe}$ rich sedimentary layers. The banding seen in the gneiss is mostly secondary, but it may in many cases originate parallel with a primary bedding. Remnants of limestone are occasionally found. At the head of Gibbs fiord highly granitized fragments of iron formation occur as garnet-pyroxene rich spots in the migmatite.

It is thus obvious that the palaeosome consists of rocks found in the overlying metasediments and the migmatite is not only the mobilized basement.

The neosome is usually more or less pegmatitic. It is partly undeformed, partly slightly tectonized. It is probably mainly a mobilizate formed by anatexis, which has been emplaced particularly in low pressure spots, like the surroundings of basic inclusions and in tension joints.

The mineralogy of the migmatite is simple and the normal granitic minerals predominate. Hornblende is particularly common in places where basic material has been assimilated. Of the alumosilicates, garnet is abundant, cordierite is found occasionally. The pegmatite is particularly rich in apatite and magnetite; rare element minerals seem to occur mainly in pegmatites emplaced outside the migmatite zone, in the transitional zone and the superstructure.

\section{The Structure}

The structural style is characterized by the disharmony between the infrastructure and the superstructure, and also by the interdependence between movements in the first-named and folding in the last-named.

At the head of Clyde Fiord, Sam Ford Fiord and McBeth Fiord, there are isolated patches of metasediments forming a comparatively thin layer on top of the migmatite. In these area the sediments are in a predominantly flat position resembling primary bedding. The texture of the rocks, however, indicates strong tectonic deformation and closer study usually unveils a tight recumbent folding (Figure 2). The position

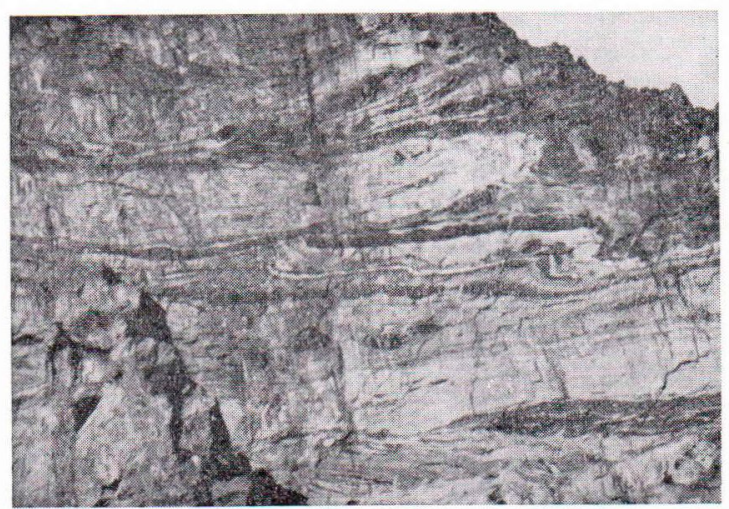

FIG. 2. Recumbent folding and thrust faulting in migmatite. Inugsuin Fiord. 


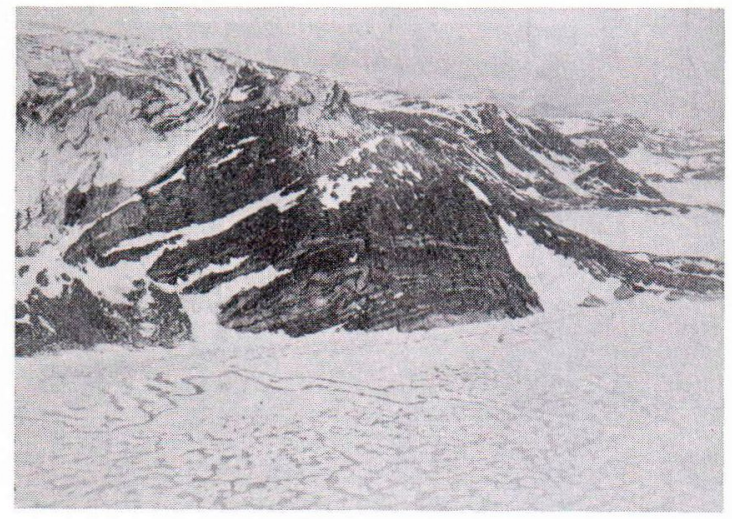

FIG. 3. Granite apophyses intruded in mica -schist, Cape Hoper.

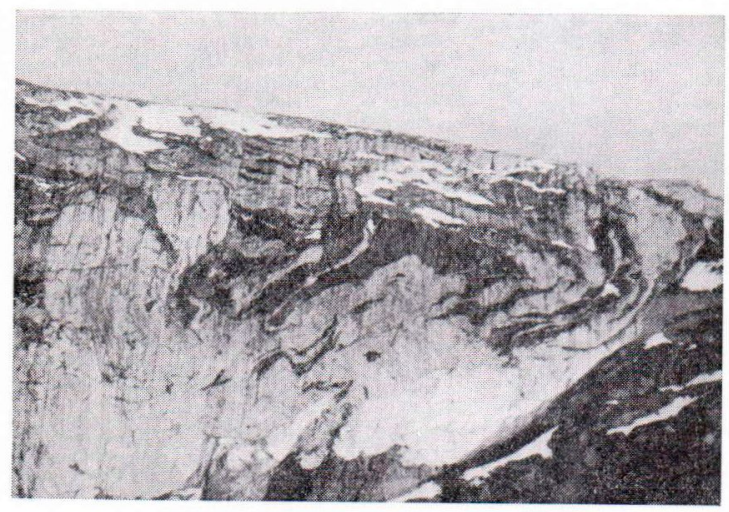

FIG. 4. Same cliff as in figure 3, in close view.

of the axial planes is sub-horizontal and appears to be approximately parallel to the dividing plane between the superstructure and the infrastructure. This behaviour is characteristic of the transitional zone in general.

Where the sediments are thicker and extend over large areas, south and west of McBeth fiord, a normal folding with steep axial planes predominates. Both large scale open folding and almost isoclinal folding occurs, the latter particularly in argillaceous schists. In the region of the McBeth river valley, the relationship between the tectonic style of the metasediments and the infrastructure is particularly clear around two big domes or lobes of migmatite rising into the metasediments. This area was studied in detail and will be dealt with in a separate paper.

Because of overburden, the north-eastern contact of the migmatite could not be studied, but there is probably a direct connection between these domes and the large migmatite area to the east.

Another type of intrusion from the infrastructure is migmatic granitic injections of different kinds. In the Home bay area farther south this activity becomes very important and has a marked effect on the contact zone. The metasediments, which here are dominantly pelitic schists and gneisses, are strongly and irregularly folded, partly in steep symmetrical folds. White granite intrudes, partly as sills and partly as big ptygmas squeezed in between the sediments forming very striking patterns of the type shown in Figure 3 and 4.

The infrastructure is well exposed in three dimensions on the fiord area of northern Baffin Island, in the same way as in the fiord region of northeast Greenland, described in the classic studies by Haller, Wegmann and other members of the team of geologists who worked the Lauge Kochs expeditions (Haller, 1955, 1958, 1970; Wegmann, 1935). It is interesting to note that the structures of both these regions are strikingly similar, in spite of an age difference of over 1000 million years. In both areas the fiord-cliffs have to be seen from a certain distance in order to be properly appreciated. In close-up, the overabundance of details makes it difficult to distinguish the main pattern, and in other places the advanced granitization may have obliterated the older structures. The most conspicuous major pattern is a subhorizontal banding which in extreme cases, seen from a distance, is reminiscent of a sedimentary bedding, which it may be in some cases. The other main pattern is flat recumbent folds with subhorizontal fold planes; in other words, about the same major structures as are found in the metasediments of the transitional zone. 
There is, in the fiord area, a well-developed persistent east-west trend of the fold axes, and a distinct linear structure subparallel to the axial direction. Because of the granitization and the coarse grain of the rocks, the lineations are often difficult to distinguish, particularly in small outcrops, but it is remarkably well revealed in aerial photographs.

This linear feature is not, of course, a textural "grain» lineation, but a lineation made visible by crenulating folding and intersecting S-planes in general. It is also found in the granitic component (the neosome) of the migmatite, and thus of rather late origin, probably connected with the development of migmatite naps and domes, etc. In the palaeosome there are generally remnants of older, pre-migmatitic lineations, contorted and displaced during the formation of the migmatite.

The following local observations are pertinent to an understanding of the general structure. At the head of Gibbs fiord, where I had the opportun ty of making some detailed studies, the subhorizontal pattern is rather diffuse and visible mainly in cliffwalls, cutting the east-west fold axes at a small angle or parallel with them. The same is the case with the recumbent folds shown in the photograph (Fig. 5). In sections perpendicular to the axial direction the folding tends to be of the accordion or hinge-type, as shown in Figure 6, or else a crenulation, where the material was a rather homogeneous schists or gneiss. The dip of the foliation shown in smail sections is therefore often steep, but because of the horizontal position of the fold axes and the axial planes we get a seemingly parallel banding or flat recumbent folds in cliffwalls cutting the longitudinal direction. The general style is explained by the schematic diagrams in Figure 7, a and $\mathrm{b}$.

This pattern seems to be very common in the whole area and it also applies to the large recumbent folds of McBeth fiord which I described in an earlier paper (Kranck, 1950).

Another feature can only be explained if we know the general tectonic style of the migmatites,

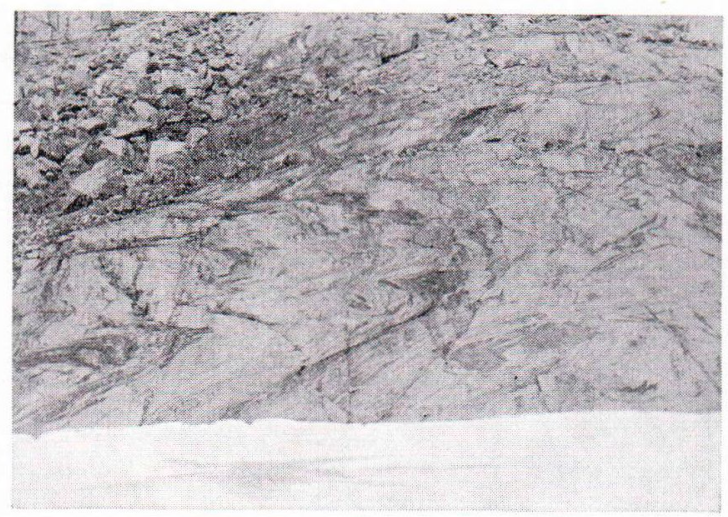

FIG. 5. Recumbent fold pattern in migmatite. McBeth Fiord.

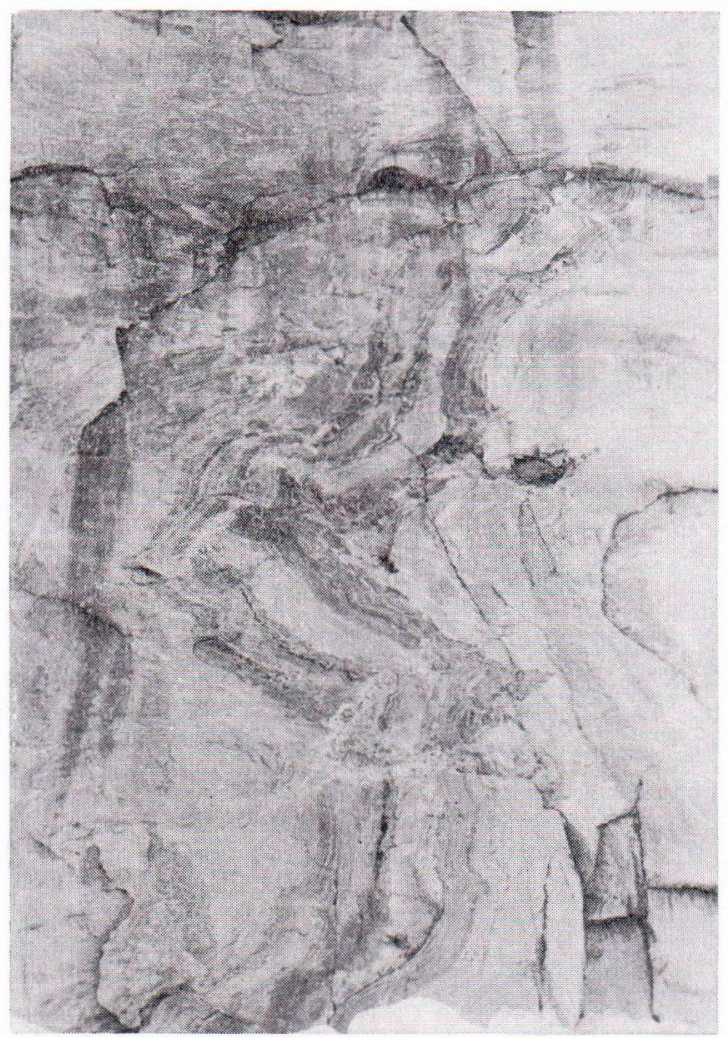

FIG. 6. Accordion-type folding with low-angle fold planes. Probably primary bedding. Gibbs Fiord.

which are large mafic inclusions of irregular shape with vertical dimensions of several hundred feet. They appear to swim in the migmatite and could be used as an argument for magamatic 
A.

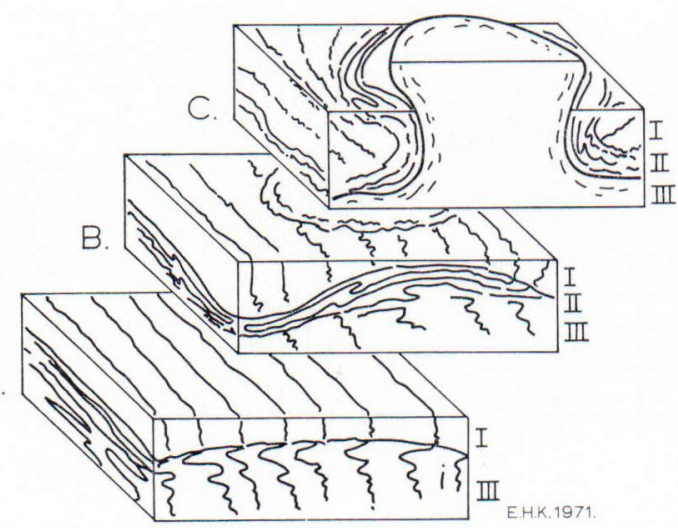

FIG. 7. Schematic stereogram showing the development of structure in migmatite on the boundary between a steeply-folded superstructure and a rising infrastructure.

I. Superstructure, II. Transitional zone, III. Infrastructure. intrusion of the latter. Its slightly sigmoidal forms indicate, however, that they represent basic layers or sills which have been disharmoniously folded with the gneisses, and because of greater »competence» form large subhorizontal accordion folds, which are cut obliquely to the fold axes by the cliff wall where they appear.

The first controlling factor of the large scale structure of the migmatites is thus the semihorizontal position of the axial planes. The second factor is a flow banding formed more or less parallel to the axial planes. The latter effect seems to be more important in the upper parts of the migmatite column.

I have earlier analyzed the kinetics of minor structures in the migmatites of northern Baffin

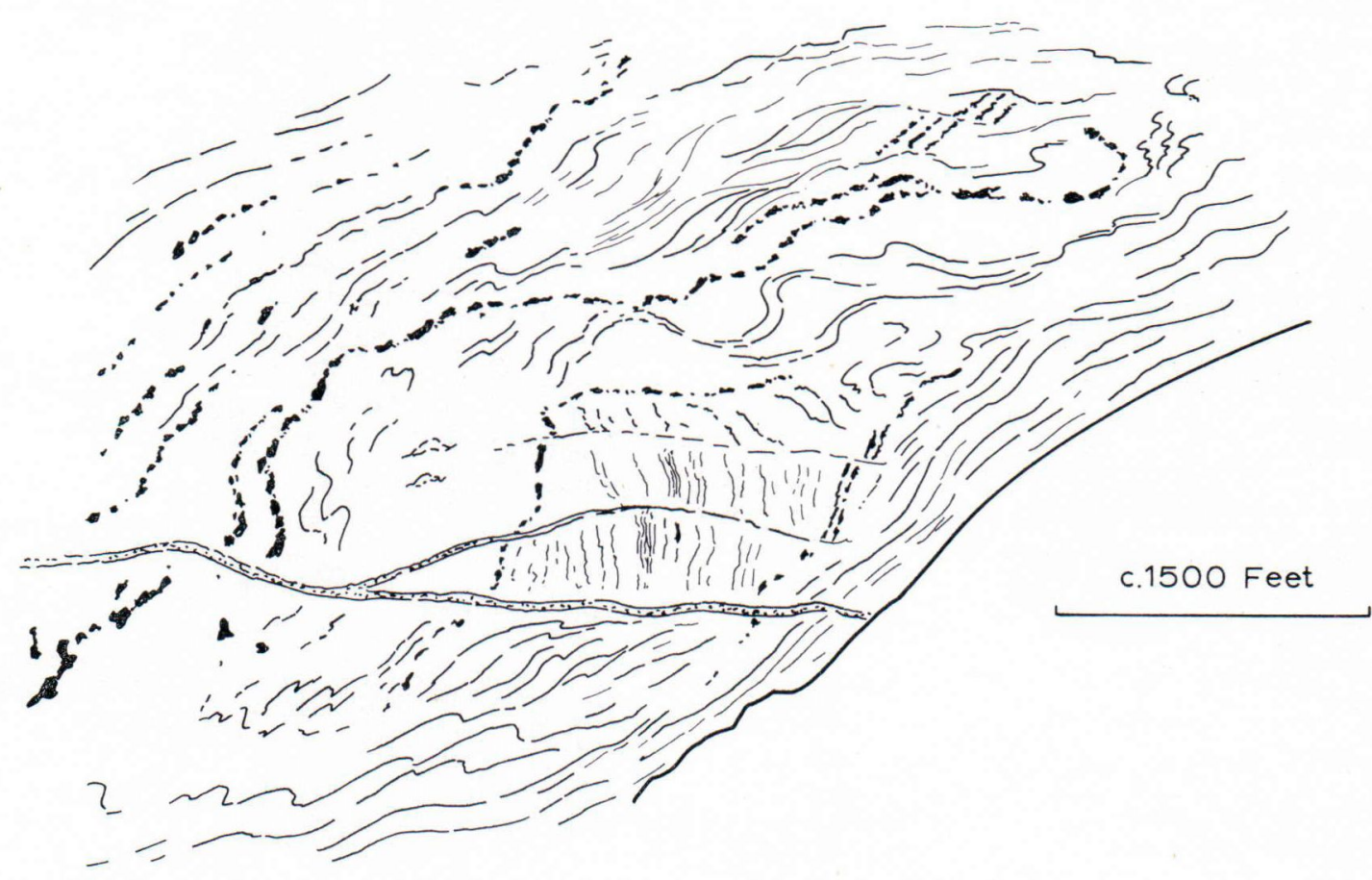

E. H.K. 1970

FIG. 8. The cliff of Clyde Fiord. In the centre remnants of older steep folding surrounded by later flowbanding connected with large scale recumbent flowfolding. 
Island (Kranck, 1953). In the following discussion the development of the general tectonic style will be briefly covered on the basis of field observations.

The observations quoted in the first part of this section show that the structures did not originate in one single process. Everywhere can be found several phases of deformation, both earlier and later than the regional granitization. For the discussion of these events the section shown in Figure 8 serves as a useful basis. It is the same section from Clyde fiord which was published as a field sketch in my 1950 report (Kranck, 1953). Figure 8 is drawn from a photograph taken by Norman Gray from a helicopter.

Cliff walls of some 3000 feet in height cut the general axial direction almost perpendicularly. The section shows in the centre a field with vertical foliation (or bedding?) representing remnats of an older structure, probably a steeply folded pelitic gneiss from the superstructure. The steep foliation is intersected by some almost horizontal fault planes. Surrounding the older structure there is strong flowbanding, presumably formed by flow movements connected with the formation of a migmatite nap. The horizontal faults may have been produced at an early stage of this flow movement.

Basic sills intruded before the deformation and migmatization have been broken up into rosarylike strings of agmatite. The fragments are mostly angular and are embedded in pegmatitic material. Finally a younger homogeneous granite intruded as dikes along the horizontal fault planes.

As a comparison to this section, a portion of a cliff wall from the head of Gibbs fiord is interesting (Figure 9). The picture shows a pelitic gneiss, probably of the same kind as in the earlier structure, but in a more advanced stage of palingenesis. The horizontal slip planes are still visible, but the old foliation is crenulated in connection with a vertical compression decreasing the distance between the slip planes.

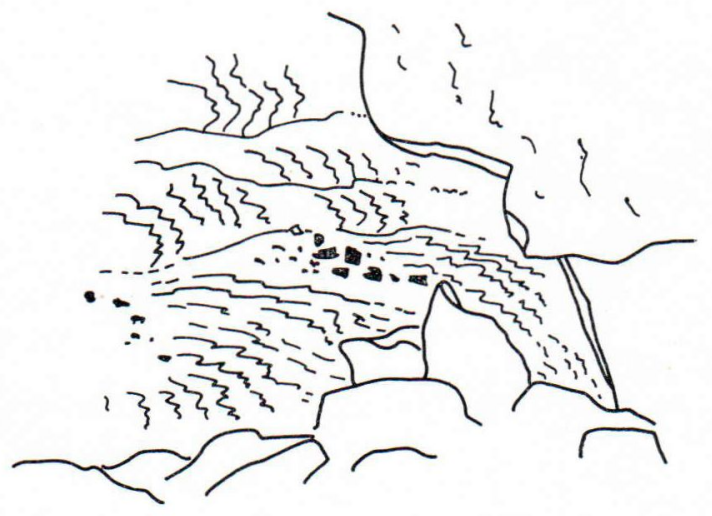

FIG. 9. Migmatite gneiss with crenulation folding and horizontal slip planes. Gibbs Fiord. Height of cliff about 20 feet.

A further development is the emplacement of neomagma along the shear planes, gradually giving rise to nebulitic structure.

\section{Gneiss Domes and Diapirs}

A striking feature in many gneiss terrains, amongst them central Baffin Island, is the occurrence of circular structures, which represent risings of the infrastructure.

Concentric circular structures may form in different ways: they may represent intersections between the present topographic surface and axial culminations of anticlines, or they may form by diapirism or other kinds of non-axial rise of the substructure. Concentric structures of the first type tend to be slightly elongated and there are often several in a row along the same anticline. In this case the depression between the domes is not circular. An ideal example of this type was described by Lauerma from West Greenland (Lauerma, 1964), but it is most probably an axial culmination because of inhomogeneity at the folded sequences. It should be emphasized that this is not a case of crossfolding. A refolding of an older folding pattern in a certain angle to the original produces a very different type of doming, mostly $\mathrm{V}$-shaped 


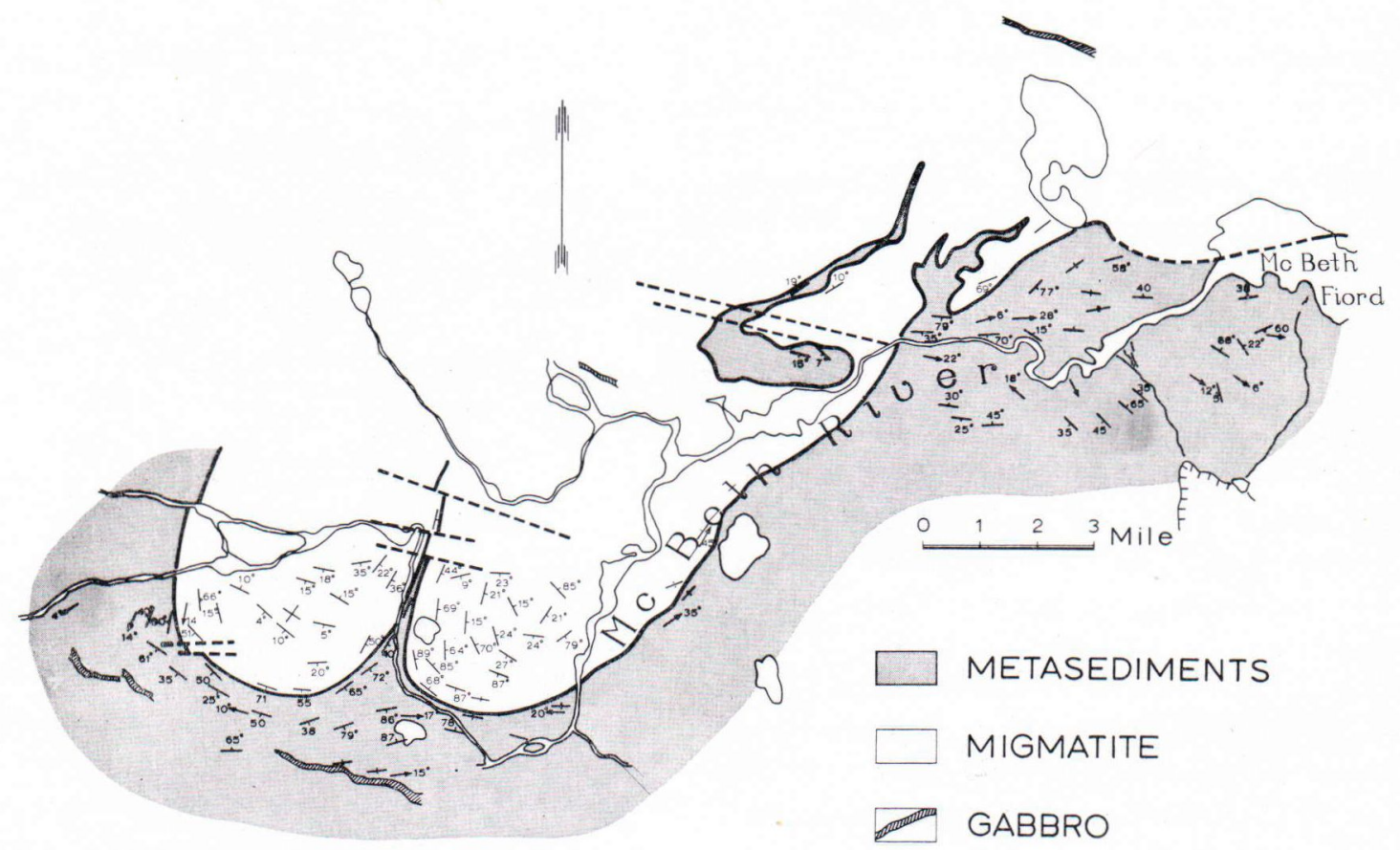

FIG. 10. Map showing the contact between metasediments and migmatite on the north side of the McBeth river valley. After Gray and Forester.

or star-shaped. A good example of the folding from Scotland described by Tobisch (Tobisch, 1966).

More complex cases of gneiss domes, mainly of nonaxial type, are the Tovqussap Nuna complex from Southwest Greenland known through the excellent studies done by Berthelsen (Berthelsen, 1960); and the Valhalla dome in British Columbia described by Reesor (Reesor, 1965, 1966). Haller describes migmatite cupolas from Northeast Greenland occurring with migmatite nappes of differing types (Haller, 1955 pp. 154-168). They all represent rising masses of plastic infrastructures and updoming of the overlying cover rocks. Operating over extensive areas, this mechanism may affect the whole style of a terrain eroded down to the level where the superstructure and infrastructure meet. In the Helsingfors region of southern Finland described by Wegmann and myself (Wegmann \& Kranck, 1931, Kranck, 1952), a characteristic feature is the formation of semicircular arches which tend to end in a sharply bent, whorllike formation. These arches probably were formed originally as semihorizontal recumbent folds of the type described above. By updoming of the infrastructure, these folded strata have been uptilted in steep positions around the infrastructural »batholiths». This process is a nonaxial deformation, schematically described in Figure $6 \mathrm{c}$.

Diapirism and the formation of piercement domes create, by the rise of material from a more plastic substratum, a more rigid superstructure. Gravitational forces were predominant. The prototype is the evaporate diapir. The diapir concept was first applied to granitoid intrusions by Wegmann in the Helsingfors (Helsinki) region (Wegmann, 1930). It must be emphasized that even if gravitational buoyancy is the principal cause of the rise of diapirs, there is often a close connection between diapirs and axial deforma- 
tion. Evaporate diapirs may form along the crest of an anticline, as is the case on Axel Heiberg Island and other regions (Kranck, 1963), and in particular, migmatite naps are generally formed by an interaction between tangential forces and gravitational forces. It is significant that the geological map of the diapir region of Axel Heiberg Island shows many similarities to Precambrian terrain with migmatite diapirs and gneiss domes.

In the fiord country of Baffin Island the two migmatite twin lobes north of the McBeth river valley represent domes formed in connection with rising migmatite naps. The well-exposed southern contact is circular. The northeastern contact is covered by overburden and it is not possible to see whether there is a direct connection between the domes and the migmatite terrain to the east, but this is probably the case.

The west lobe consists of migmatite with rather welldeveloped foliation, which is horizontal at the centre dipping increasingly toward the periphery, but generally not more than $50^{\circ}$. The east lobe is predominantly granitic, particularly in the centre, but with almost vertical dip at the contacts, suggesting a diapiric intrusion.

The east dome, which according to Gray and Forester was probably formed later than the north dome, has been thrust against the latter in a way shown by Figure 11. The metasediments have been squeezed into a steep position between the domes and are pushed into a concentric position around the other contacts of the lobes. Along the contact of the east lobe there is a thin limestone skarn horizon which seems to mark the

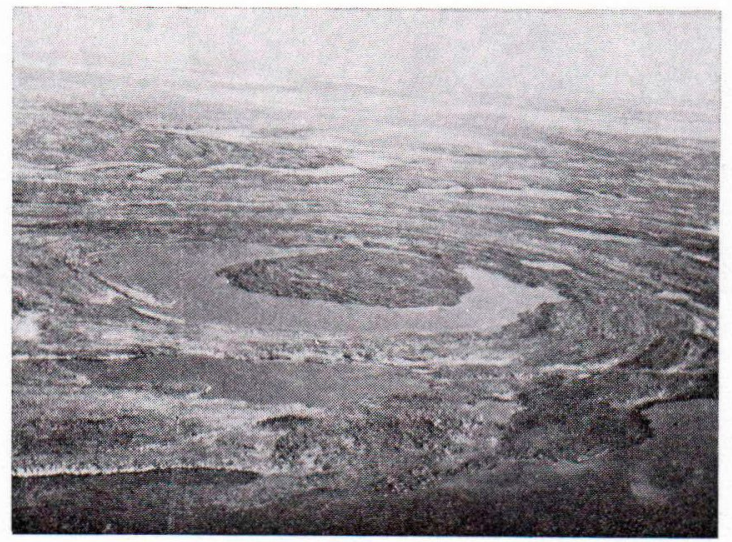

Fig. 12. Circular structure north of Netteling Lake.

level to which the migmatite front rose. The same horizon is also found in the west lobe, but here as interrupted bands within the dome. Sillimanite quartz nodules form a characteristic constituent in this horizon, and similar contacts are also found farther east at the north shore of the fiord (Kranck 1955). Around the domes pegmatite dikes are very numerous.

A striking example of a simple diapir is the circular structure photographed by me in 1950 north of Netteling lake in central Baffin Island (Figure 12). I interpreted it as a gneiss basin (Kranck, 1959), an assumption which was confirmed during the mapping carried out by the Geological Survey of Canada in 1970. The structure is visible on the topographic sheet and is situated at $67^{\circ} 14^{\prime} \mathrm{N}, 69^{\circ} 10^{\prime} \mathrm{E}$. Because of the perfect circular bowl shape, the interpretation of its origin has been subject to some controversy,

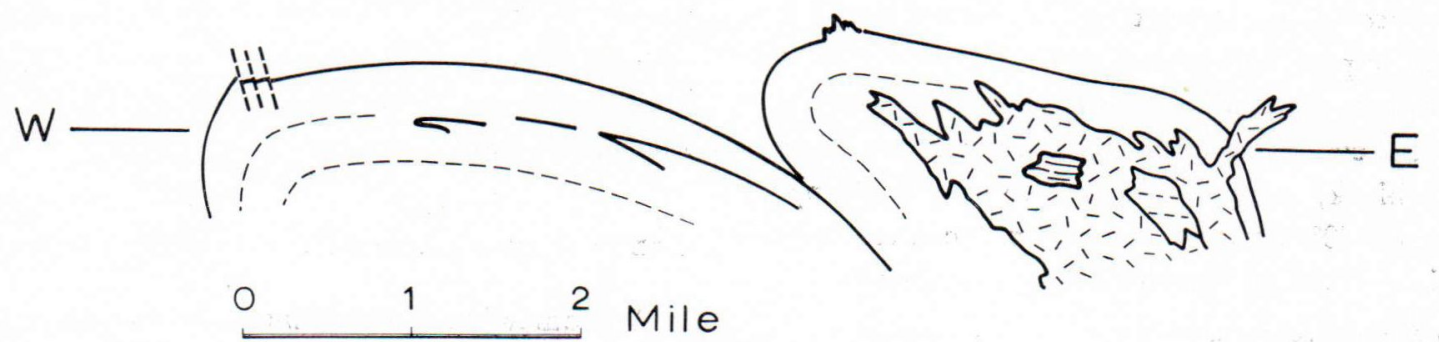

FIG. 11. Cross section through the migmatite lobes of the McBeth river val -y. After Gray and Forester. 


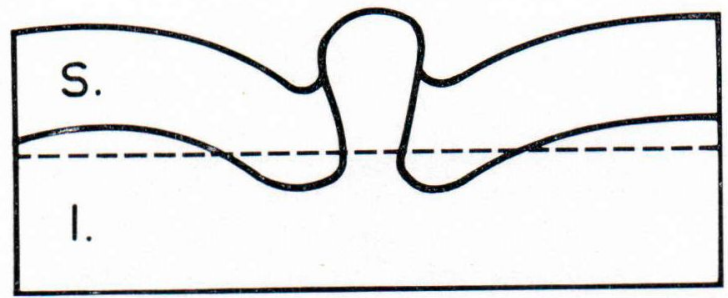

FIG. 13. Diapir produced by centrifuged model. After Ramberg. Dotted line shows the present erosion level of Figure 12.

and it has even been suggested that it may represent a meteoric impact-crater. To my mind it is most probably a diapir. The pertinent, features are a centre of granitic material (coarse migmatite) surrounded by concentric rings of metasediments. The surrounding bedrock consists of the migmatite granite of the infrastructure, with the sediments seeming to form a rather thin cap on top of the first-named. The bowl shape may seem to contradict the idea of a diapir, but if we compare the structure with the experimental diapir of Ramberg (Ramberg, 1963, p. 44) shown in Figure 13, we have a perfect similarity. The bowl shape is exactly what we can expect in a section where only the lower part of the sedimentary cover is preserved. We find all the features of the model, also the small swelling in the middle of the ring structure. ${ }^{1}$

Another interesting ring structure of much larger dimensions, marked by the shape of lakes, is visible on the topographic sheet about 70 miles west of the DEW line station of Dewar Lake. Dr. G. Jackson, in charge of the helicopter party of the Geological Survey of Canada, kindly gave me the opportunity to fly in to this locality. Approaching by air from the east one has almost the impression of entering a huge caldera. The eastern edge of the structure in an arcshaped ridge consisting of metasediments with a horizon of black, sulphide-rich schists on top, dipping about $40^{\circ}$ outwards. On the western side of the ring structure, the ringwall is not as well devel-

1) A circular bowl could, of course, be formed by deep erosion of an axial depression of a syncline, but this would not account for the granite in the centre. oped, and is eroded down to the level of the surrounding gneiss terrain. The centre of the dome consists of coarse-grained migmatite granite. The whole structure is intersected by some very large pegmatite dikes, which stand out in the topography as steep walls rising to 150 feet above the surrounding terrain. Whether the dome is formed by erosion of an axial culmination or is a diapiric dome is still an open question.

Circular structures of this type seem to occur elsewhere between Dewar lake and Netteling lake.

It is interesting that at Dewar lake we again find the predominantly low angle position of the foliation forming gentle, open folds. In a creek bed southwest of the airstrip, the quartzitic gneiss shows a well developed, tight, smallscale flat chevron folding, indicating that the kinetics of deformation here were of the same type as in the fiord region discussed earlier in this paper, with the rising infrastructure as the compressing factor.

The rise of the infrastructure at the formation of the domes and diapirs was most probably caused by gravitational buoyancy, as Ramberg's experiments suggest. I should not, however, entirely exclude the possibility of geostatic pressure in some cases, caused by a rather thin, more »competent» rock cover on top of a more plastic substructure; that is, a process taking place within a level of the earth's crust where directed stress dominates. This is because of the many known cases where diapir structures consist of more dense material than the overlying sediments. The anhydrite diapirs in the Arctic archipelago, for example, are more dense than the sediments into which they intrude. This may also be the case with the anorthosites of Morin Heights, Quebec, interpreted as rising domes by Martignole and Schrijver (1970).

\section{Conclusions - Rise of the Infrastructure}

The somewhat scattered information quoted in this paper is naturally insufficient for the forma- 
tion of any conclusions about the regional structure of the area, but does provide a rough idea of the tectonic style and the kinetics, which agrees with a great number of descriptions of migmatite terrains throughout the world. I have tried to emphasize the importance of the formation of recumbent folds with low angle axial planes and in general sub-horizontal foliation in connection with the rise of the plastic infrastructure relative to the superstructure. The first-named tend to flow along the more rigid superstructure, initially in a more or less horizontal manner, but gradually forming domes and finally forming diapirs of migmatite granite. Around such domes, the originally subhorizontal flow folds are tilted outwards, and the fold axes and fold planes brought into steep positions. A special case of this sequence of events is the formation of migmatite nappes.

The flattening of the migmatite-gneiss structures by the spreading out of the rising infrastructure has recently been discussed by Martignole and Schrijver (1971) in their study of the Grenville rocks north of Montreal, and their interpretations agree with the conclusions drawn in this paper. The problem of the low angle foliation of highly metamorphic gneiss terrain has also been discussed by Fyson (1971) from much the same point of view.

As far as the general picture of migmatite tectonics is concerned, Haller's work in Northeast Greenland still provides the most instructive models, particularly because it shows the actual relationship between the superstructure and infrastructure in geological scale sections in the field (Haller, 1971).

The rise of the infrastructure emphasized in this paper is a process taking place in the deeper portions of the crust, and essentially independent of the orogenic forces which affect the orogenic belt as a whole. It is mainly controlled by gravitational forces and is connected with granitization and the origin of a low density granitoid horizon at about the level where one has the lowest melting temperature of the granitic cotecticum (Kranck, 1971, p. 53).

There is another kind of rise of the infrastructure, or perhaps more correctly the basement zone, which is connected with the deformation of the whole orogenic belt, caused by outside forces. This gives rise to the paraautochthonous massifs such as the Aar massif, and in general large-scale vaulting, lifting portions of the basement to the level of unmetamorphosed cover rocks. The slices of basement found in the large nappes of Penninic type must also originate in the same kind of process. These processes belong to a higher tectonic level, where the crust was rather rigid, and the deformational forces released along restricted zones of dislocation rather than as a differential flow.

In the interpretation of structures in metamorphic rocks, especially in the field, one must take into account the fact that subhorizontal foliation produced by the spread of the infrastructure along the subsurface of the superstructure gives much the same pattern as the structures formed by the overriding of slices of the crust as nappes. The mechanism which controlled the minor structures is essentially the same. Both are controlled by gravitation but working in opposite directions (Buoyancy Load).

Acknowledgments - I wish to express my thanks to my co-workers, Norman Gray and Richard Forester, for the excellent field work in the McBeth river region, and for their permission to use the results in this paper. I would also like to thank Dr. G. Jackson of the Geological Survey of Canada for his kind hospitality and assistance during a most interesting stay at the Survey's base camp in Baffin Island in 1970. It also gives me great pleasure to acknowledge with gratitude permission that was given for Gray and Forester to use the base camp of the Geographic branch of the Department of Mines and Natural Resources during part of their work in the McBeth river valley. Finally I wish to thank Mrs. Jean Eakins for help with editing and preparation of the manuscript.

This study was supported by National Research Council of Canada Grant A-2 634. 


\section{REFERENCES}

Berthelsen, A. (1960) Structural studies in the preCambrian of western Greenland II. Geology of Tovqussap Nuna. Medd. Gronland. Bd 123, Vol 1, $180 \mathrm{p}$.

Fahrig, W. F., Irving, E., Jackson, G. D. (1971) Paleomagnetism of the Franklin diabases. Can. Journ. Earth Sc. V. 8, p. 455.

Fyson, W. K. (1971) Fold attitudes in metamorphic rocks. Am. Journ. Sc. V. 250, pp. 366-375.

Gray, N. H. (1970) Growth and nucleation in two large diabase dikes. Can. Journ. Earth Sc. V. 8 pp. $366-375$.

- and Forester R. (1967) Unpublished preliminary report to National Research Council of Canada.

Haller, J. (1955) Der Zentrale Metamorphe Komplex von NE Gronland. Medd. Gronland. Bd 73.3, 174 p.

- (1958) Der geologische Karte Staunig Alps und des Forsblom Fjordes. Medd. Gronland. Bd 154.3, 154 p.

- (1970) Tectonic map of East Greenland (1: 50 000). Medd Gronland, Bd 171, 86 p.

IrviNG E. (1971) (Fahrig, Jackson).

JACKson, G. D. (1969) Reconnaissance of north-central Baffin Island. In Report of Activities. Geol. Surv. Can. Paper 69-1, Part A, pp. 171-176.

- (1971) Operation Penny Highlands, south-central Baffin Island. In Report of Activities, Geol. Surv. Can., Paper 71-1, Part A, pp. 138-140.

- (1971) (Fahrig, Irving).

Kranck, E. H. (1953) Interpretation of gneiss structures with special reference to Baffin Island. Proceedings Geol. Ass. Canada. pp. 59-68.

- (1955) The bedrock geology of the Clyde-area in Northern Baffin Island. Acta Geographica, 14. 22 p.

- (1959) On folding movements in the zone of the basement. Geol. Rundschau, B. 46, pp. 261-282.

- (1963) Tectonics of evaporite diapirs on Axel Heiberg Island. Jacobsen-McGill Arctic expedition to Axel Heiberg Island, Prel. Report. pp. 133-138.

- (1971) The granite cycle and oremineralization. Scientific colloquium, E. Raguin, Paris 1971 (in print).

- and WegmanN, C. E. (1931) Beitrage zur Kenntniss der Scecofenniden in Finnland.
Lauerma, Raimo (1964) On the structure and petrology of the Ipernat dome, Western Greenland. Bull. Comm. Géol. Finlande 215. pp. 1-88. C. R. Soc. Géol. Finlande 36. pp 1-88.

Martignole, J. and Schrijver, K. (1970) Tectonic setting and evolution of the Morin anorthosite, Grenville province, Quebec, Bull. Geol. Soc. Finland, 42, pp. $165-209$.

Mehnert, K. R. (1968) Migmatites and the origin of granitic rocks. Elsevier publishing co.

RamberG, H. (1963) Experimental study of gravity tectonics by means of centrifuged models. Bull. geol. inst. University Uppsala, vol. XLII, pp. 1-97.

- (1966) The Scandinavian Caledonides as studied by centrifuged models. Ibid. Vol. XLII, pp. 1-72.

REESOR, J. E. (1965) Structural evolution and plutonism in Valhalla gneiss complex, B. C. G.S.C. Bull. 129 p.

- (1966) The Thor-Odin gneiss dome, Monashee Mountain, Southern British Columbia. G.S.C. Bull. 66, pp. $78-80$.

Tobish, Otmar T. (1966) Large Scale Basin and Dome pattern resulting from the interference of major folds. Geol. Soc. Am. Bull. V. 77, pp. 396-408.

Wegmann, C. E. (1930) Uber Diapirismus (Besonders in Grundgebirge) C. R. Geol. Soc. Finlande. No. 3, pp. $1-30$.

- and KRANCK, E. H. (1931) Beitrage zur Kenntnis der Svecofenniden in Finnland, I, II, Bull. Comm. Geol. Finlande 89.

- (1953) Über Gleichzeitige Bewegungsbilder verschiedener Stockwerke. Geol. Rundschau, B. 41, pp. 21-33.

- (1935) Preliminary report on the Caledonian orogeny in Christian X's Land (North-East Greenland). Md. Gronland. B. 103, Nr. 3.

- (1935) Zur Deutung der Migmatite. Geol. Rundschau. B. XXVI. 5. pp. $305-350$.

Manuscript received, January 3, 1972. 